Tips om medisinsk litteratur, andre bøker, filmer og elektroniske medier som bør anmeldes, sendes tidsskriftet@legeforeningen.no

\section{En god og nøktern beskrivelse av mindfulness i psykologisk behandling}

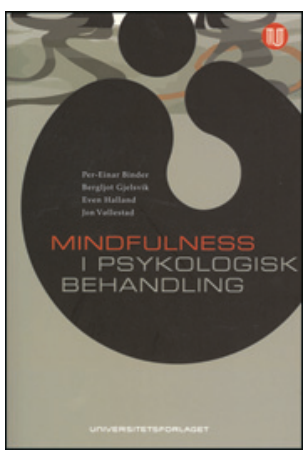

Per-Einar Binder, Bergljot Gjelsvik,

Even Halland et al.

Mindfulness i psykologisk behandling

204 s. Oslo: Universitetsforlaget, 2014

Pris NOK 349

ISBN 978-82-15-02116-4

Denne utgivelsen retter seg mot helsepersonell med interesse for bruk av oppmerksomt nærvær («mindfulness») i behandling av psykologiske problemer og sykdommer. Forfatterne er alle psykologer som selv har praktisert «mindfulness» i flere år, og som har erfaring med bruk av «mindfulness»-baserte tilnærminger både $i$ individualbehandling og i grupper. De er i tillegg sertifiserte instruktører innenfor de mest brukte «mindfulness»-programmer i helsetjenesten i dag, nemlig «mindfulness-based stress reduction» (MBSR) og «mindfulness-based cognitive therapy» (MBCT).

Boken er bygd opp med innledende kapitler om hva oppmerksomt nærvær er innenfor en vestlig psykologisk forståelsesramme, hvordan det praktiseres, og på hvilken måte det kan utvide vårt perspektiv på lidelse og lindring av denne. Deretter redegjøres for fremveksten av oppmerksomt nærvær innenfor ulike retninger av psykologisk behandling, samt pågående forskning innenfor dette feltet. Så følger et meget instruktivt kapittel om hva som kjennetegner «mindfulness»-basert arbeid i grupper, og hva som er viktig å passe på under ledelse av slike grupper. Etter et kapittel der forfatterne viser hvordan grunnholdningene i oppmerksomt nærvær er sentrale innenfor ulike eksisterende retninger av psykoterapeutisk behandling, følger kapitler som gjennomgår bruken av oppmerksomhetsøvelser i psykoterapi, i behandling av stress, depresjon og angstlidelser. Boken avsluttes med et godt og nødvendig kapittel som drøfter farene i den pågående «mindfulness»-bølgen, med en nyttig drøfting av nødvendige standarder for terapeuter som ønsker å ta i bruk trening i oppmerksomt nærvær. Boken er godt underbygd av fyldige referanser til forskningslitteratur.

Drøftingen av «mindfulness»-begrepet i en vestlig kontekst er god og nøktern, men kunne kanskje vært utvidet med en grundigere gjennomgang av hvordan dette skiller seg fra den opprinnelige bruken av oppmerksomt nærvær innen buddhistiske tradisjoner. Sentrale trekk ved «mindfulness»»-basert terapi gjentas noe i de ulike kapitlene som tar for seg behandling av stress, angst og depresjon, kanskje fordi de er skrevet av ulike forfattere. Disse to mindre innvendingene forstyrrer ikke det gode totalinntrykket av boken, som trygt kan anbefales for alle som ønsker en nøktern og balansert beskrivelse av oppmerksomt nærvær innen psykologisk behandling.

\section{Michael de Vibe}

Seniorrådgiver

Nasjonalt kunnskapssenter for helsetjenesten, Seksjon for kvalitetsutvikling

Oppgitte interessekonflikter: Anmelder har sittet i styret i Norsk forening for oppmerksomt nærvær innen helse, utdanning og forskning, der tre av forfatterne også har hatt verv.

\section{Forskning om lesbiske og homofiles levekår i Norge}

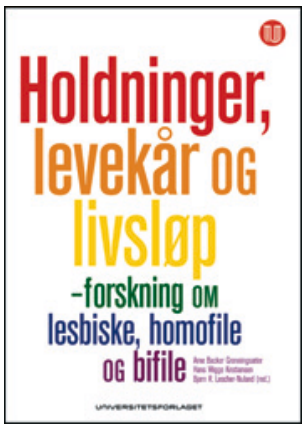

Arne Backer Grønningsæter, Hans Wiggo Kristiansen, Bjørn R. Lescher-Nuland, red. Holdninger, levekår og livsløp

Forskning om lesbiske, homofile og bifile. 187 s, tab. Oslo: Universitetsforlaget, 2013. Pris NOK 359

ISBN 978-82-15-02224-6

Denne utgivelsen har som mål å presentere forskning om LHBpopulasjonen (lesbiske, homofile og bifile) i Norge. Målgruppen er ikke klart definert, men er nok, foruten LHB-populasjonen selv, myndigheter og organisasjoner som arbeider med LHB-spørsmål.

Boken består av åtte kapitler av ulike forfattere og omhandler temaer som holdninger til homoseksualitet i befolkningen, lesbiske, homofile og bifile med nedsatt funksjonsevne, hiv blant menn som har sex med menn, lesbiske, homofile og bifile i arbeidslivet, lesbiske personers møte med helsevesenet og, til slutt, aldring og omsorgsbehov i LHB-populasjonen.

Bak kapitteloverskriften «Lesbisk selvtillit i møtet med legen» skjuler det seg en utmerket oversikt over de metodiske problemene med LHB-forskningen i Norge og internasjonalt. Hva vil det si å være lesbisk eller homofil? Tar studiene innover seg at seksuell orientering omfatter tiltrekning, atferd og identitet? Er materialet representativt? LHB-studiene baserer seg nærmest utelukkende på tilgjengelighetsutvalg - kan funnene her sammenliknes med data for den heterofile befolkningen fra representative befolkningsundersøkelser? Hva er overførbarheten til hele LHB-populasjonen når deltakerne er rekruttert gjennom LHB-organisasjoner eller på møtesteder for lesbiske, homofile og bifile? Er antallet deltakere høyt nok? For det meste av LHB-forskningen i Norge er svaret nedslående. Det som finnes av representative befolkningsunders $\varnothing$ kelser, for eksempel Statistisk sentralbyrås levekårsundersøkelse fra 2010, har for lavt antall ikke-heterofile til at man kan trekke konklusjoner relatert til seksuell orientering. Det er et stort innslag av kvalitative metoder i de norske LHB-studiene, og her stiller særlig problemene med rekrutteringsutvalg store krav til hvordan funnene presenteres. Forfatterne av ovennevnte kapittel, Bjørkman og Malterud, viser hvordan kvalitative data kan presenteres på en nøktern måte og bidrar til å kaste lys over kvantitative funn.

Det gamle kravet om mer forskning gjelder altså også her. Forskning er nødvendig for å identifisere områder hvor det fremdeles er en skjevfordeling, og hvor det er behov for tiltak. Flere internasjonale undersøkelser viser en økt forekomst av psykiske lidelser, særlig hos kvinner og unge. Minoritetsstress - tilleggsbelastningen man blir utsatt for som følge av sin minoritetsposisjon - er veldokumentert, det samme er forbindelsen mellom stigma og helseproblemer. Utfordringen blir så å velge riktige tiltak for å bøte på skjevfordelingen, og her er vi på enda tynnere is forskningsmessig.

\section{Eirik Pettersen}

Lege i spesialisering, Infeksjonsmedisinsk avdeling Akershus universitetssykehus 